Article

\title{
Anti-Leishmanial and Cytotoxic Activities of a Series of Maleimides: Synthesis, Biological Evaluation and Structure-Activity Relationship
}

\author{
Yongxian Fan ${ }^{1}$, Yuele Lu ${ }^{1}$, Xiaolong Chen ${ }^{1, *}$, Babu Tekwani ${ }^{2}$, Xing-Cong Li ${ }^{2}$ and \\ Yinchu Shen ${ }^{1}$ \\ 1 Institute of Fermentation Engineering, College of Biotechnology and Bioengineering, Zhejiang University of \\ Technology, 18\# Chaowang Road, Hangzhou 310032, China; lilyfan@zjut.edu.cn (Y.F.); \\ luyuele@zjut.edu.cn (Y.L.); syc@zjut.edu.cn (Y.S.) \\ 2 National Center for Natural Products Research, Research Institute of Pharmaceutical Sciences and \\ Department of BioMolecular Sciences, School of Pharmacy, The University of Mississippi, \\ University, MS 38677, USA; btekwani@olemiss.edu (B.T.); xcli7@olemiss.edu (X.-C.L.) \\ * Correspondence: richard_chen@zjut.edu.cn; Tel.: +86-571-88320571
}

Academic Editors: Muhammad Ilias and Charles L. Cantrell

Received: 25 September 2018; Accepted: 31 October 2018; Published: 5 November 2018

\begin{abstract}
In the present study, 45 maleimides have been synthesized and evaluated for anti-leishmanial activities against $L$. donovani in vitro and cytotoxicity toward THP1 cells. All compounds exhibited obvious anti-leishmanial activities. Among the tested compounds, there were 10 maleimides with superior anti-leishmanial activities to standard drug amphotericin B, and 32 maleimides with superior anti-leishmanial activities to standard drug pentamidine, especially compounds $\mathbf{1 6}\left(\mathrm{IC}_{50}<0.0128 \mu \mathrm{g} / \mathrm{mL}\right)$ and $42\left(\mathrm{IC}_{50}<0.0128 \mu \mathrm{g} / \mathrm{mL}\right)$, which showed extraordinary efficacy in an in vitro test and low cytotoxicities $\left(\mathrm{CC}_{50}>10 \mu \mathrm{g} / \mathrm{mL}\right)$. The anti-leishmanial activities of $\mathbf{1 6}$ and $\mathbf{4 2}$ were 10 times better than that of amphotericin B. The structure and activity relationship (SAR) studies revealed that 3,4-non-substituted maleimides displayed the strongest anti-leishmanial activities compared to those for 3-methyl-maleimides and 3,4-dichloro-maleimides. 3,4-dichloro-maleimides were the least cytotoxic compared to 3-methyl-maleimides and 3,4-non-substituted maleimides. The results show that several of the reported compounds are promising leads for potential anti-leishmanial drug development.
\end{abstract}

Keywords: anti-leishmanial activity; Leishmania donovani; maleimides; cytotoxicity; SAR

\section{Introduction}

Leishmaniasis, which is caused by several species of Leishmania, is one of the major tropical diseases defined by the World Health Organization (WHO), affecting about 12 million people [1,2]. A wide range of clinical manifestations are encompassed, including visceral leishmaniasis, cutaneous leishmaniasis, and mucocutaneous leishmaniasis. Among them, visceral leishmaniasis is the most severe form of the disease. Visceral leishmaniasis, also called black fever or Kala-azar, has a fatality rate as high as 100\% within two years if untreated, and spontaneous cure is extremely rare [3,4]. Visceral leishmaniasis is found throughout the intertropical and temperate regions, and threatens around 350 million people in 88 countries. Up to now, few medicines have been available for leishmaniasis. Pentostam is the most widely used drug, which contains the heavy metal antimony. Other medicines, such as amphotericin B and its derivatives [5], liposomal amphotericin B [5], paromomycin [6], and miltefosine [7], have their individual problems, such as toxicity, poor efficacy, or high cost. Meanwhile, the emerging drug-resistant parasites have caused further problems for therapy of the disease. Therefore, the discovery of new types of medicines with novel chemical structures is highly desirable. 
Recently, other candidate compounds, including buparvaquone [8], aminoquinolines [9], peptoids [10], (4-arylpiperazin-1-yl)(1-(thiophen-2-yl)-9H-pyrido[3,4-b]indol-3-yl) methanone derivatives [11], amino acid-triazole hybrids [12], biscoumarins [13], triazolyl quinoline derivatives [14], benzopiperidine, benzopyridine and phenyl piperazine based compounds [15], 2,5-diarylidene cyclohexanones [16], natamycin [17], piperazinyl- $\beta$-carboline derivatives [18], thiosemicarbazones [19], and so on, were evaluated and investigated. But for most of them, the $\mathrm{IC}_{50} \mathrm{~s}$ of anti-leishmanial activities still remained to be in micromolar ranges except thiosemicarbazones (two compounds had the $\mathrm{IC}_{50} \mathrm{~s}$ of $0.060 \mu \mathrm{g} / \mathrm{mL}$ and $0.068 \mu \mathrm{g} / \mathrm{mL}$ against promastigotes of L. major.) [19].

Maleimides, including natural products with maleimide core moiety, had excellent biological activities, including antimicrobial [20-28] and enzyme inhibition activities [29-31]. $\mathrm{N}$-(4-Fluorophenyl)-dichloro-maleimide, significantly inhibiting fungal growth, was first developed and used to control the diseases of apple scab, rice blast and tomato late blight [32]. The MICs of $\mathrm{N}$-butyl-maleimide and $\mathrm{N}$-(4-phenylbutyl)-maleimide against 10 fungi were in the range of $0.48-15.63 \mu \mathrm{g} / \mathrm{mL}$, similar to that of ampicillin, and had little toxicity to humans [33]. The antimicrobial mechanism was investigated and found that maleimides could interact preferably with the hydrophobic domains of target enzymes resulting in inactivation of sulfhydryl groups [29], which were essential for their catalytic activities. The activities were greatly affected by the structure of $C=C$ double bond in the circle of diimide. For instance, $N$-ethyl-maleimide (NEM) and $N$-tert-butyl-maleimide inhibited $\beta$-(1,3)-glucan synthase with $\mathrm{IC}_{50}$ values $8.5 \pm 1.1 \mu \mathrm{g} / \mathrm{mL}, 13.7 \pm 2.3 \mu \mathrm{g} / \mathrm{mL}$, respectively, and then influenced microbial growth [34]. In addition to great antimicrobial activities, maleimides had also been widely researched in medicine as antianxiety [35], anti-inflammatory [36], anticancer [37,38] and neuroprotective agents.

However, it should be noted that the reported studies were mainly focused on antimicrobial activity. No anti-leishmanial activity of maleimides has been reported before this. In the present work, a series of $\mathrm{N}$-substituted maleimides, methyl-maleimides, and dichloro-maleimides were synthesized, and their anti-leishmanial effects in vitro and cytotoxicity toward THP1 cells were investigated. The results suggest that some of the synthesized maleimides might be developed as the anti-leishmanial drugs in the future.

\section{Results and Discussion}

\subsection{Chemistry}

All maleimides were synthesized employing two methods according to an improved procedure based on the reported methods [22,32,33], using amines and maleic anhydrides as starting materials (Scheme 1). Path A was a facile method by one-step reaction to prepare 3,4-dichloromaleimides and 3-methylmaleimides with shorter reaction time, especially for synthesis of the former. However, path B was used to prepare $\mathrm{N}$-alkylmaleimides (1-4) by two-step reactions, dehydration and ring-closing reaction. Furthermore, path A had higher yields and an easier isolation method when compared to path B. The desired compound could be easily synthesized in good yield (more than 70\%) in one or two steps, as either crystalline or oily compound.

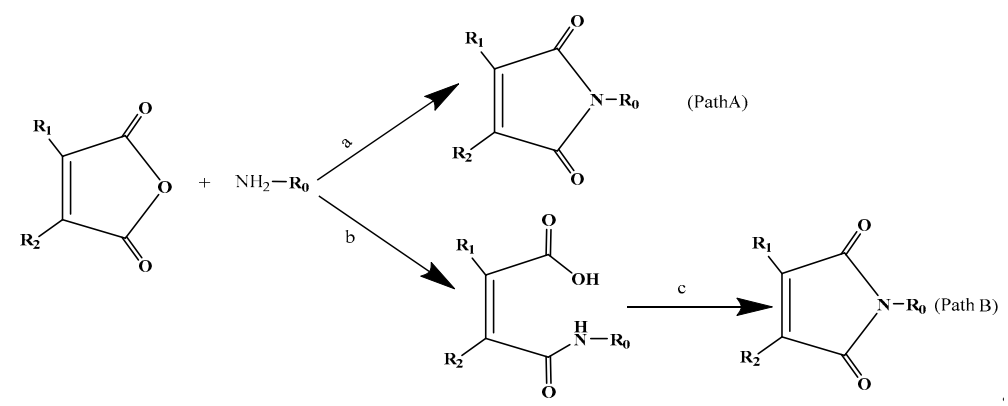

Scheme 1. Synthesis of $\mathrm{N}$-substituted maleimide derivatives. Path A: a. $\mathrm{CH}_{3} \mathrm{COOH}$. Path B: b. toluene, 25-65 ${ }^{\circ} \mathrm{C}, 2-8$ h; c. $\mathrm{CH}_{3} \mathrm{COONa},(\mathrm{Et})_{3} \mathrm{~N}, 101^{\circ} \mathrm{C}, 10-24 \mathrm{~h}$. 


\subsection{Biological Evaluations}

\subsubsection{Anti-leishmanial Activity}

45 maleimides [20,29,32,33] (Figure 1) and two drugs, pentamidine (Figure 2) and amphotericin B (Figure 3), were evaluated against L. donovani, to identify the most active compounds that are worthy of further investigation (Table 1). Anti-leishmanial activity in vitro was described in terms of $\mathrm{IC}_{50}$, which is the effective concentration $(\mu \mathrm{g} / \mathrm{mL})$ required to achieve $50 \%$ growth inhibition, with promastigotes in their exponential growth phase. Most of tested compounds had good anti-leishmanial activities ( $\mathrm{IC}_{50} \mathrm{~s}$ for 41 compounds were less than $1 \mu \mathrm{g} / \mathrm{mL}$ ). Among them, the $\mathrm{IC}_{50} \mathrm{~s}$ of 16 and 42 were less than $0.0128 \mu \mathrm{g} / \mathrm{mL}$, much less than those of amphotericin $\mathrm{B}\left(\mathrm{IC}_{50}=0.12 \mu \mathrm{g} / \mathrm{mL}\right)$ and pentamidine $\left(\mathrm{IC}_{50}=0.64 \mu \mathrm{g} / \mathrm{mL}\right)$, which reached nanogram grade. These activities were stronger than most compounds in literature [8-19]. There were another eight candidate compounds $(\mathbf{1}, \mathbf{3}, \mathbf{6}, \mathbf{7}, \mathbf{8}, \mathbf{1 3}$, 14, and 41) which had better activities than amphotericin B.
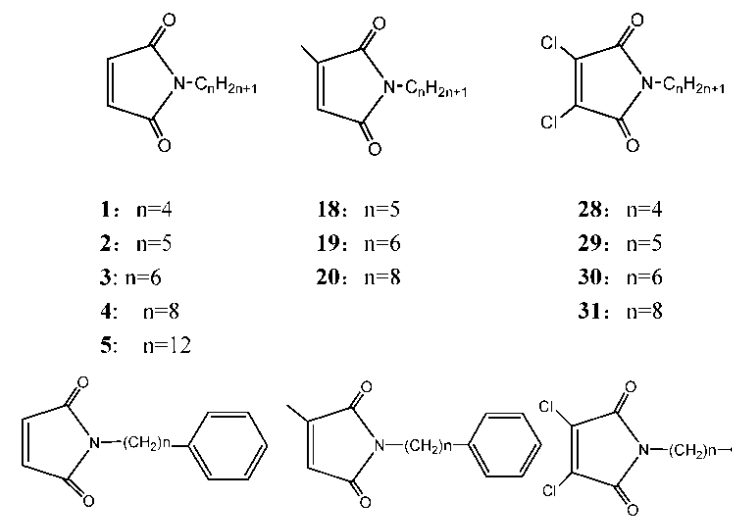

18: $n=5$

19: $n=6$

28: $n=4$

20: $n=8$

29: $n=5$

30: $n=6$

31: $\mathrm{n}=8$

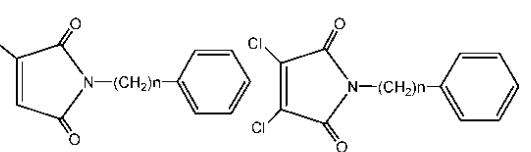

6: $n=1$

21: $n=1$

32: $n=2$

7: $n=2$

22: $n=2$

33: $n=3$

8: $n=3$
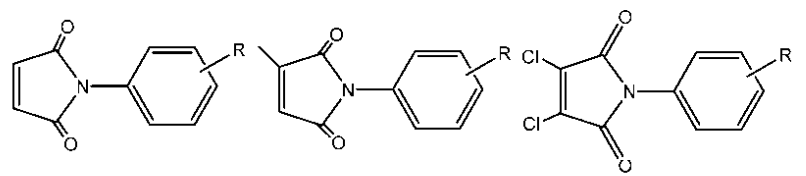

9: $\mathrm{R}=\mathrm{H}$

23: $\mathrm{R}=2,6-\left(\mathrm{CH}_{3}\right)_{2}$

34: $\mathrm{R}=\mathrm{H}$

10: $\mathrm{R}=4-\mathrm{CH}_{3}$

24: $\mathrm{R}=2,6-\left(\mathrm{C}_{2} \mathrm{H}_{5}\right)$

35: $\mathrm{R}=4-\mathrm{C}$

11: $R=4-F$

25: $\mathrm{R}=3,5-(\mathrm{Cl})$ ?

36: $\mathrm{R}=4-\mathrm{F}$

37: $\mathrm{R}=4-\mathrm{Cl}$

38: $\mathrm{R}=2,6-\left(\mathrm{CH}_{3}\right)_{2}$

13: $\mathrm{R}=2,6-\left(\mathrm{CH}_{3}\right)_{2}$

14: $\mathrm{R}=2,6-\left(\mathrm{C}_{2} \mathrm{H}_{5}\right)$

39: $\mathrm{R}=2,6-\left(\mathrm{C}_{2} \mathrm{H}_{5}\right)_{2}$

40: $\mathrm{R}=2-\mathrm{CII}_{3}-3-\mathrm{Cl}$

41: $\mathrm{R}=2-\mathrm{CH}_{3}-5-\mathrm{Cl}$

42: $\mathrm{R}=2-\mathrm{CH}_{3}-3-\mathrm{NO}_{2}$

43: $\mathrm{R}=3,5-(\mathrm{Cl})_{2}$<smiles>CC(C)CN1C(=O)C=CC1=O</smiles>

16<smiles>CC1=CC(=O)N(CC(C)C)C1=O</smiles>

26<smiles>CC(C)CN1C(=O)C(Cl)=C(Cl)C1=O</smiles><smiles>CC1=CC(=O)N(C2CCCCC2)C1=O</smiles>

Figure 1. Chemical structures of the studied $N$-substituted maleimides. 
<smiles>N=C(N)c1ccc(OCCCCCOc2ccc(C(=N)N)cc2)cc1</smiles>

Figure 2. The chemical structure of pentamidine.

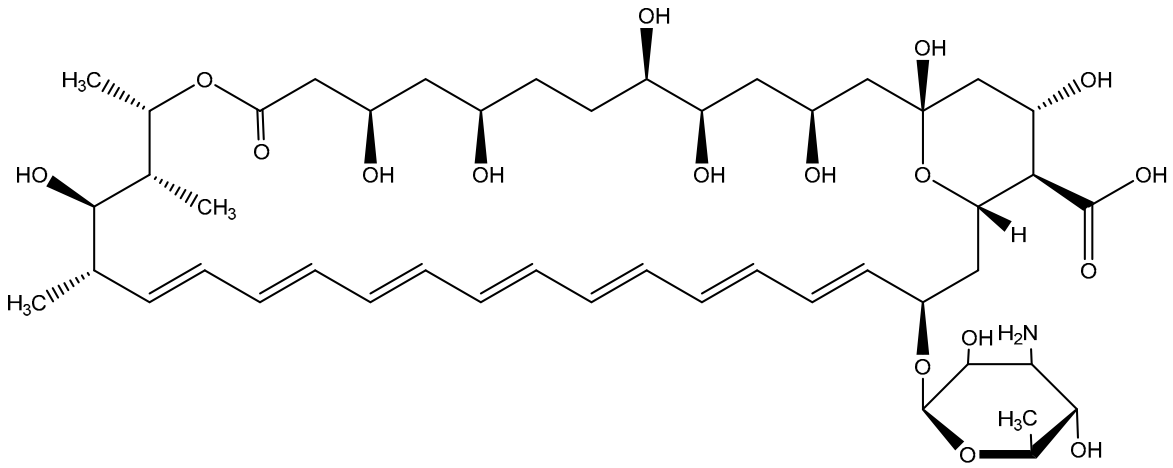

Figure 3. The chemical structure of amphotericin B.

Table 1. Anti-leishmanial activities and cytotoxicity of maleimides 1-45, pentamidine and amphotericin B.

\begin{tabular}{|c|c|c|c|c|}
\hline Compound & L. donvani $\mathrm{IC}_{50}(\mu \mathrm{g} / \mathrm{mL})$ & THP1 CC $50(\mu \mathrm{g} / \mathrm{mL})$ & SI & $\log P$ \\
\hline 1 & 0.08 & $>10$ & $>125.0$ & 0.72 \\
\hline 2 & 0.36 & $>10$ & $>27.8$ & 1.14 \\
\hline 3 & 0.11 & $>10$ & $>90.9$ & 1.56 \\
\hline 4 & 0.27 & $>10$ & $>37.0$ & 2.39 \\
\hline 5 & 2.21 & $>10$ & $>4.5$ & 4.06 \\
\hline 6 & 0.08 & 4.56 & 57.0 & 1.21 \\
\hline 7 & 0.10 & 4.13 & 41.3 & 1.49 \\
\hline 8 & 0.11 & 8.25 & 75.0 & 1.91 \\
\hline 9 & 0.24 & $>10$ & $>41.7$ & 1.14 \\
\hline 10 & 0.15 & $>10$ & $>66.7$ & 1.63 \\
\hline 11 & 0.32 & $>10$ & $>31.3$ & 1.30 \\
\hline 12 & 1.02 & $>10$ & $>9.8$ & 1.70 \\
\hline 13 & 0.10 & 3.65 & 36.5 & 2.12 \\
\hline 14 & 0.08 & 3.89 & 48.6 & 2.95 \\
\hline 15 & 0.21 & $>10$ & $>23.2$ & 1.62 \\
\hline 16 & $<0.0128$ & $>10$ & $>781.3$ & 0.70 \\
\hline 17 & 0.26 & $>10$ & $>38.5$ & 1.03 \\
\hline 18 & 0.58 & 7.64 & 13.2 & 1.07 \\
\hline 19 & 0.81 & 5.89 & 7.3 & 1.91 \\
\hline 20 & 0.96 & 8.10 & 8.4 & 2.74 \\
\hline 21 & 0.58 & 7.94 & 13.7 & 1.56 \\
\hline 22 & 1.22 & 5.99 & 4.9 & 1.84 \\
\hline 23 & 13.17 & $>10$ & $>0.8$ & 2.47 \\
\hline 24 & 0.55 & 4.39 & 8.0 & 3.30 \\
\hline 25 & 0.34 & 0.80 & 2.4 & 2.61 \\
\hline 26 & 0.64 & $>10$ & $>15.6$ & 1.05 \\
\hline 27 & 0.89 & 7.15 & 8.0 & 1.38 \\
\hline 28 & 0.47 & $>10$ & $>21.3$ & 0.80 \\
\hline 29 & 0.65 & $>10$ & $>15.4$ & 1.22 \\
\hline 30 & 0.49 & $>10$ & $>20.4$ & 1.63 \\
\hline 31 & 0.48 & $>10$ & $>20.8$ & 2.47 \\
\hline 32 & 1.64 & $>10$ & $>6.1$ & 1.57 \\
\hline 33 & 0.40 & $>10$ & $>25.0$ & 1.99 \\
\hline 34 & 0.76 & $>10$ & $>13.2$ & 1.22 \\
\hline
\end{tabular}


Table 1. Cont.

\begin{tabular}{ccccc}
\hline Compound & L. donvani IC $_{\mathbf{5 0}}(\boldsymbol{\mu g} / \mathrm{mL})$ & THP1 $_{\text {CC }} \mathbf{5 0}(\boldsymbol{\mu g} / \mathrm{mL})$ & SI & LogP \\
\hline $\mathbf{3 5}$ & 0.66 & $>10$ & $>15.2$ & 1.71 \\
$\mathbf{3 6}$ & 0.36 & $>10$ & $>27.8$ & 1.38 \\
$\mathbf{3 7}$ & 0.59 & $>10$ & $>16.9$ & 1.78 \\
$\mathbf{3 8}$ & 0.45 & $>10$ & $>22.2$ & 2.19 \\
$\mathbf{3 9}$ & 0.13 & $>10$ & $>76.9$ & 3.03 \\
$\mathbf{4 0}$ & 0.13 & $>10$ & $>76.9$ & 2.27 \\
$\mathbf{4 1}$ & 0.11 & $>10$ & $>90.9$ & 2.27 \\
$\mathbf{4 2}$ & $<0.0128$ & $>10$ & $>781.3$ & 1.70 \\
$\mathbf{4 3}$ & 0.99 & $>10$ & $>10.1$ & 2.34 \\
$\mathbf{4 4}$ & 0.43 & $>10$ & $>23.3$ & 0.78 \\
$\mathbf{4 5}$ & 0.26 & $>10$ & $>38.5$ & 1.10 \\
pentamidine & 0.64 & $\mathrm{ND}$ & - & 2.84 \\
amphotericin B & 0.12 & $\mathrm{ND}$ & - & 2.30 \\
\hline
\end{tabular}

\subsubsection{Cytotoxicity}

In order to verify the safety of maleimides, they were tested for cytotoxicity against human monocytic leukemia cells (THP1) 50\% cytotoxic concentration values represent the concentration of compound required to kill $50 \%$ of the THP1 cells were calculated $\left(\mathrm{CC}_{50}\right)$. The selectivity indices were calculated using the formula $\mathrm{SI}=\mathrm{CC}_{50} / \mathrm{IC}_{50}$, against promastigotes. Interestingly, $\mathrm{CC}_{50} \mathrm{~S}$ of 31 out of 45 maleimides were greater than $10 \mu \mathrm{g} / \mathrm{mL}$, which highlighted their safety on mammalian cells (Table 1). SIs of $\mathbf{1 6}$ and $\mathbf{4 2}$ were greater than 781.3.

\subsection{Structure-Activity Relationships}

\subsubsection{Influences of Substituents at the 3- and 4-Positions of the Maleimide Ring}

As shown in Table 1, the introduction of substituents at the 3- and 4-positions on the maleimide ring had different influences on the anti-leishmanial activities against $L$. donovani, depending on the type of introduced substituents. In general, 3,4-non-substituted maleimides (1-17) displayed very strong anti-leishmanial activities, with $\mathrm{IC}_{50}$ values ranging from 0.0128 to $2.21 \mu \mathrm{g} / \mathrm{mL}$, 0.336 on the average, comparing to $1.774 \mu \mathrm{g} / \mathrm{mL}$ for 3-methyl-maleimides and $0.501 \mu \mathrm{g} / \mathrm{mL}$ for 3,4-dichloro-maleimides. Especially, 1, 3, 6, 7, 8, 13, 14, and 16 showed more interesting anti-leishmanial activities than the corresponding 3-methyl-maleimides and 3,4-dichloro-maleimides, which were superior or much superior to amphotericin $B\left(\mathrm{IC}_{50}=0.12 \mu \mathrm{g} / \mathrm{mL}\right)$. In them, 15 compounds had better activities than pentamidine $\left(\mathrm{IC}_{50}=0.64 \mu \mathrm{g} / \mathrm{mL}\right)$ except $5\left(\mathrm{IC}_{50}=2.21 \mu \mathrm{g} / \mathrm{mL}\right)$ and $12\left(\mathrm{IC}_{50}=1.02 \mu \mathrm{g} / \mathrm{mL}\right)$. Moreover, 16 and 42 displayed the strongest anti-leishmanial activity $\left(\mathrm{IC}_{50}<0.0128 \mu \mathrm{g} / \mathrm{mL}\right)$. However, there was no apparent regularity for the influences of variation in substituents at the 3 - and 4-positions on the maleimide ring. As to cytotoxicity, 3,4-dichloro-maleimides were least cytotoxic, whose $\mathrm{CC}_{50} \mathrm{~s}$ were all higher than $10 \mu \mathrm{g} / \mathrm{mL}$. Furthermore, 3-methyl-maleimides (18-27) were the most cytotoxic, whose $\mathrm{CC}_{50}$ s were all less than $10 \mu \mathrm{g} / \mathrm{mL}$.

\subsubsection{Influences of the $N$-Substituents}

Influences of variation in the alkyl chain length. Results in Table 1 show that the $N$-alkyl substituents ( 1 to 5,18 to 20 and 28 to 31 ) had influences on anti-leishmanial activity. As the length of the $N$-alkyl chain increased, the anti-leishmanial activity decreased significantly. However, 1 exhibited the highest anti-leishmanial activity, with an $\mathrm{IC}_{50}$ of $0.08 \mu \mathrm{g} / \mathrm{mL}$, which was one of the compounds with the best activity. It could possibly be explained that with the change in the polarity and $\mathrm{N}$-alkyl chain length, their ability to connect enzymes differs. Therefore, with variation in chain length, 1 to 5,18 to 20 and 28 to 31 had different influences on anti-leishmanial activities. It was observed that $N$-phenylalkyl substituents ( 6 to 8,21 to 22 and 32 and 33) showed a correlation with the 
anti-leishmanial activity against $L$. donovani. As the alkyl chain length of $N$-phenylalkyl substituents increased, the anti-leishmanial activities decreased gradually (except for 33), which might be explained by the $\mathrm{N}-\mathrm{C}$ distance between the two rings playing an important role in the anti-leishmanial activities of these compounds.

Influences of the substituted benzene ring. As for compounds with a mono-substituent on position 4 of phenyl ring, such as $\mathbf{1 0}$ to 12, and $\mathbf{3 5}$ to 37, it was obvious that the different groups had different influences on the inhibition. However, there was no apparent regularity for the effects of variation with a mono-substituent on position 4 of phenyl ring. Furthermore, compounds 13 to 14,24 to 25 and 38 to 43 with double substituents on benzene ring displayed much stronger anti-leishmanial activity against L. donovani. However, positions of the substituents had apparent influences on the inhibition behavior. For example, N-2-methyl-3-nitro-substituted compound (42) exhibited the highest anti-leishmanial activity $\left(\mathrm{IC}_{50}<0.0128 \mu \mathrm{g} / \mathrm{mL}\right.$ ). And 13, 14, 39, 40, and 41 also showed very strong anti-leishmanial activity $\left(\mathrm{IC}_{50}\right.$ ranged from $0.08-0.13 \mu \mathrm{g} / \mathrm{mL}$ ). In spite of these factors, steric hindrances might affect anti-leishmanial activity. From the results in Table 1, it can be concluded that the $\log \mathrm{P}$ value (predicted by Chemoffice 2014) is an important parameter influencing the anti-leishmanial activities against L. donovani. However, there was no apparent regularity between the $\mathrm{IC}_{50}$ values and $\log \mathrm{P}$ values on the whole.

\section{Experimental Section}

\subsection{Chemistry General Details}

Starting materials were obtained from Aldrich and used as received. Melting points (MP) were measured with a WRS-1A melting point apparatus, and were uncorrected. ${ }^{1} \mathrm{H}-\mathrm{NMR}$ spectra were recorded on a Bruker AVANCE III 500 spectrometer (Bruker, London, UK) at $500 \mathrm{MHz}$ using tetramethylsilane (TMS) as an internal standard. Electrospray ionization-mass spectra (EIMS) were measured on a mass spectrometer (Thermo Fisher Scientific, LCQ/ADVANTAGE, 81 Wyman Street, Waltham, MA, USA). IR spectrum was recorded in KBr pellets on a Nicolet 6700 infrared spectrophotometer (Thermo Fisher Scientific, 81 Wyman Street, Waltham, MA, USA).

The structures of all the compounds were determined by IR, EI-MS, ${ }^{1} \mathrm{H}-\mathrm{NMR}$. Note that compounds $\mathbf{1 - 1 2}, \mathbf{1 7}, \mathbf{2 1}, \mathbf{2 2}, \mathbf{2 8 - 3 7}$ had been previously reported [27,33,39-43], which were coincident with the previous report by EI MS and ${ }^{1} \mathrm{H}-\mathrm{NMR}$. Physical and spectroscopic data of the other compounds were shown in the supplementary material.

\subsection{Biology}

In vitro anti-leishmanial assay. The antileishmanial activity of the compounds was tested in vitro against a culture of L. donovani promastigotes [44]. The promastigotes were grown in RPMI 1640 medium supplemented with $10 \%$ fetal calf serum (Gibco Chem. Co., 81 Wyman Street, Waltham, MA, USA) at $26^{\circ} \mathrm{C}$. A three day old culture was diluted to $5 \times 10^{5}$ promastigotes $/ \mathrm{mL}$. Drug dilutions were prepared directly in cell suspension in 96-well plates. Plates were incubated at $26{ }^{\circ} \mathrm{C}$ for $48 \mathrm{~h}$ and the growth of Leishmania promastigotes was determined by the Alamar blue assay as described earlier [45]. Standard fluorescence was measured on a Fluostar Galaxy plate reader (BMG Lab Technologies, Offenburg, Germany) at an excitation wavelength of $544 \mathrm{~nm}$ and an emission wavelength of $590 \mathrm{~nm}$. Pentamidine and amphotericin B were used as the standard anti-leishmanial agents. $\mathrm{IC}_{50}$ values were computed from dose-response curves as above. The tested compounds were diluted with six concentrations (from $40-0.0128 \mu \mathrm{g} / \mathrm{mL}$ ). Cytotoxicity assay. The in vitro cytotoxicity was determined against human monocytic leukemia cells (THP1) with a simple colorimetric method using the dye Alamar Blue [45]. THP1 suspensions were grown in RPMI-1640 medium supplemented with $10 \% \mathrm{FBS}, 2 \mathrm{mM}$ glutamine, $50 \mu \mathrm{g} / \mathrm{mL}$ gentamicin and $0.0025 \mathrm{mg} / \mathrm{L}$ of amphotericin B (Sigma) at $37^{\circ} \mathrm{C}$ in a $5 \% \mathrm{CO}_{2}$ atmosphere. Cells were grown to a density between 0.2 and $1 \times 10^{6}$ cells $/ \mathrm{mL}$. Culture 
medium was replaced every 2-3 days with fresh growth medium. DMSO was used as the solvent, and the test compounds was with six concentrations from $10-0.0032 \mu \mathrm{g} / \mathrm{mL}$.

\section{Conclusions}

In summary, a series of maleimides have been synthesized and evaluated for inhibitory activities against L. donovani. All compounds exhibited obvious anti-leishmanial activities, especially with compounds 16 and 42 showing extraordinary potency in an in vitro test and low cytotoxicity. The anti-leishmanial activities of the two compounds were 10 times better than that of amphotericin B. Therefore, further preclinical studies of $\mathbf{1 6}$ and $\mathbf{4 2}$ aimed at leishmaniasis are important for the therapy of this neglected disease. The cytotoxicity of these compounds was low, with nearly no toxicity $(>10 \mu \mathrm{g} / \mathrm{mL}$ ). Thus, compounds $\mathbf{1 6}$ and $\mathbf{4 2}$ are promising candidates for visceral leishmaniasis. Among the tested compounds, there were 10 maleimides with superior anti-leishmanial activities to amphotericin $B$, and 32 maleimides with superior anti-leishmanial activities to pentamidine. The SAR study showed that 3,4-non-substituted maleimides displayed the strongest anti-leishmanial activities compared to those 3-methyl-maleimides and 3,4-dichloro-maleimides. When the length of the alkyl side chain ( $\mathrm{N}$-alkyl and $\mathrm{N}$-phenylalkyl) increased, the anti-leishmanial activities decreased significantly. There was no obvious regularity for the influences of variation with a mono-substituent on phenyl ring position 4. And the position of the substituent had an obvious influence on the inhibition behavior. As to cytotoxicity, 3, 4-dichloro-maleimides were least cytotoxic compared to 3-methyl-maleimides and 3,4-non-substituted maleimides.

Supplementary Materials: The following are available online, the structure data of all maleimides and the biological methods in detail.

Author Contributions: Conceptualization, Y.X. and X.C.; Methodology, Y.X. and B.T.; Software, Y.L.; Validation, X.C., Y.S., B.T. and X.-C.L.; Formal Analysis, Y.L.; Investigation, X.C.; Resources, X.C.; Data Curation, Y.X. and Y.F.; Writing-Original Draft Preparation, Y.F., X.C., Y.L. and X.-C.L.; Writing-Review \& Editing, Y.F., Y.L. And X.-C.L.; Visualization, Y.L. and Y.X.; Supervision, Y.S. and X.C.; Project Administration, X.C.; Funding Acquisition, X.C.

Funding: This study received financial support from the National Natural Science Foundation of China (Grant No. 21572206 and No. 21172198).

Conflicts of Interest: The authors declare no conflict of interest.

\section{References}

1. World Health Organization. Available online: www.who.int/leishmaniasis/burden/en/ (accessed on 1 September 2017).

2. $\quad$ Akopyants, N.S.; Kimblin, N.; Secundino, N.; Patrick, R.; Peters, N.; Lawyer, P.; Dobson, D.E.; Beverley, S.M.; Sacks, D.L. Demonstration of genetic exchange during cyclical development of Leishmania in the sand fly vector. Science 2009, 324, 265-268. [CrossRef] [PubMed]

3. Chappuis, F.; Sundar, S.; Hailu, A.; Ghalib, H.; Rijal, S.; Peeling, R.W.; Alvar, J.; Boelaert, M. Visceral leishmaniasis: What are the needs for diagnosis, treatment and control. Nat. Rev. Microbiol. 2007, 5, 873-882. [CrossRef] [PubMed]

4. Sharma, U.; Singh, S. Immunobiology of leishmaniasis. Indian J. Exp. Biol. 2009, 47, 412-423. [PubMed]

5. Golenser, J.; Domb, B. New formulations and derivatives of amphotericin B for treatment of leishmaniasis. Mini-Rev. Med. Chem. 2006, 6, 153-162. [CrossRef] [PubMed]

6. Wiwanitkit, V. Interest in paromomycin for the treatment of visceral leishmaniasis (kala-azar). Ther. Clin. Risk Manag. 2012, 8, 323-328. [CrossRef] [PubMed]

7. Dorlo, T.P.C.; Balasegaram, M.; Beijnen, J.H.; de Vries, P.J. Miltefosine: A review of its pharmacology and therapeutic efficacy in the treatment of leishmaniasis. J. Antimicrob. Chemother. 2012, 67, 2576-2597. [CrossRef] [PubMed]

8. Garnier, T.; Mantyla, A.; Jarvinen, T.; Lawrence, J.; Brown, M.; Croft, S. In vivo studies on the antileishmanial activity of buparvaquone and its prodrugs. J. Antimicrob. Chemother. 2007, 60, 802-810. [CrossRef] [PubMed] 
9. Kaur, K.; Jain, M.; Khan, S.; Jacob, M.R.; Tekwani, B.L.; Singh, S.; Singh, P.P.; Jain, R. Synthesis, antiprotozoal, antimicrobial, beta-hematin inhibition, cytotoxicity and methemoglobin (MetHb) formation activities of bis(8-aminoquinolines). Bioorg. Med. Chem. 2011, 19, 197-210. [CrossRef] [PubMed]

10. Bolt, H.L.; Denny, P.W.; Cobb, S.L. An Efficient Method for the Synthesis of Peptoids with Mixed Lysine-type/Arginine-type Monomers and Evaluation of Their Anti-leishmanial Activity. J. Vis. Exp. Jove 2016, 117, 1-12. [CrossRef] [PubMed]

11. Ashok, P.; Chander, S.; Chow, L.M.C.; Wong, I.L.K.; Singh, R.P.; Jha, P.N.; Sankaranarayanan, M. Synthesis and in-vitro anti-leishmanial activity of (4-arylpiperazin-1-yl)(1-(thiophen-2-yl)-9H-pyrido[3, 4-b]indol-3-yl)methanone derivatives. Bioorg. Chem. 2017, 70, 100-106. [CrossRef] [PubMed]

12. Masood, M.M.; Hasan, P.; Tabrez, S.; Ahmad, M.B.; Yadava, U.; Daniliuc, C.G.; Sonawane, Y.A.; Azam, A.; Rub, A.; Abid, M. Anti-leishmanial and cytotoxic activities of amino acid-triazole hybrids: Synthesis, biological evaluation, molecular docking and in silico physico-chemical properties. Bioorg. Med. Chem. Lett. 2017, 27, 1886-1891. [CrossRef] [PubMed]

13. Rahim, F.; Samreen, H.; Ullah, H.; Fakhri, M.I.; Salar, U.; Perveen, S.; Khan, K.M.; Iqbal Choudhary, M. Anti-leishmanial activities of synthetic biscoumarins. J. Chem. Soc. Pak. 2017, 39, 79-82.

14. Upadhyay, A.; Kushwaha, P.; Gupta, S.; Dodda, R.P.; Ramalingam, K.; Kant, R.; Goyal, N.; Sashidhara, K.V. Synthesis and evaluation of novel triazolyl quinoline derivatives as potential antileishmanial agents. Eur. J. Med. Chem. 2018, 154, 172-181. [CrossRef] [PubMed]

15. Chander, S.; Ashok, P.; Reguera, R.; Perez-Pertejo, M.; Carbajo-Andres, R.; Balana-Fouce, R.; Sankaranarayanan, M. Synthesis and activity of benzopiperidine, benzopyridine and phenyl piperazine based compounds against Leishmania infantum. Exp. Parasitol. 2018, 189, 49-60. [CrossRef] [PubMed]

16. Din, Z.U.; Trapp, M.A.; Soman de Medeiros, L.; Lazarin-Bidoia, D.; Garcia, F.P.; Peron, F.; Nakamura, C.V.; Rodriguez, I.C.; Wadood, A.; Rodrigues-Filho, E. Symmetrical and unsymmetrical substituted 2,5-diarylidene cyclohexanones as anti-parasitic compounds. Eur. J. Med. Chem. 2018, 155, 596-608. [CrossRef] [PubMed]

17. Awasthi, B.P.; Mitra, K. In vitro leishmanicidal effects of the anti-fungal drug natamycin are mediated through disruption of calcium homeostasis and mitochondrial dysfunction. Apoptosis 2018, 23, 420-435. [CrossRef] [PubMed]

18. Ashok, P.; Chander, S.; Smith, T.K.; Sankaranarayanan, M. Design, synthesis and biological evaluation of piperazinyl- $\beta$-carboline derivatives as anti-leishmanial agents. Eur. J. Med. Chem. 2018, 150, 559-566. [CrossRef] [PubMed]

19. Temraz, M.G.; Elzahhar, P.A.; El-Din, A.; Bekhit, A.; Bekhit, A.A.; Labib, H.F.; Belal, A.S.F. Anti-leishmanial click modifiable thiosemicarbazones: design, synthesis, biological evaluation and in silico studies. Eur. J. Med. Chem. 2018, 151, 585-600. [CrossRef] [PubMed]

20. Chen, X.L.; Zhang, L.J.; Li, F.G.; Fan, Y.X.; Wang, W.P.; Li, B.J.; Shen, Y.C. Synthesis and antifungal evaluation of a series of maleimides. Pest Manag. Sci. 2015, 71, 433-440. [CrossRef] [PubMed]

21. Li, W.; Fan, Y.X.; Shen, Z.Z.; Chen, X.L.; Shen, Y.C. Antifungal activity of simple compounds with maleic anhydride or dimethylmaleimide structure against Botrytis cinerea. J. Pestic. Sci. 2012, 37, $247-251$. [CrossRef]

22. Shen, Z.Z.; Fan, Y.X.; Li, F.G.; Chen, X.L.; Shen, Y.C. Synthesis of a series of N-substituted dimethylmaleimides and their antifungal activities against Sclerotinia sclerotiorum. J. Pest Sci. 2013, 86, 353-360. [CrossRef]

23. Jens, R.A.; Irma, K.B.; Beata, A.C.; Anthony, C.W.A.; Edward, H.D.; Stephen, S.B.; Edward, T.C.; Vito, F.D. The synthesis and biological evaluation of two analogues of the C-Riboside showdomycin. Aust. J. Chem. 2005, 58, 86-93.

24. Thomas, B.; Stephan, A.S. Showdomycin as a versatile chemical tool for the detection of pathogenesis-associated enzymes in bacteria. J. Am. Chem. Soc. 2010, 132, 6964-6972.

25. Wu, M.D.; Cheng, M.J. Maleimide and maleic anhydride derivatives from the mycelia of Antrodia cinnamomea and their nitric oxide inhibitory activities in macrophages. J. Nat. Prod. 2008, 71, 1258-1261. [CrossRef] [PubMed]

26. Wael, A.Z.; Clarisse, B.F.; Fondja, Y.; Aqabamycins, A.-G. Novel nitro maleimides from a marine Vibrio species: I. taxonomy, fermentation, isolation and biological activities. J. Antibiot. 2010, 63, 297-301.

27. Frederic, Z.; Alain, V. Synthesis and antimicrobial activities of $N$-substituted imides. IL Farmaco 2002, 57, 421-426. 
28. David, C.; Emmanuelle, S.S. Monohalogenated maleimides as potential agents for the inhibition of Pseudomonas aeruginosa biofilm. Biofouling 2010, 26, 379-385.

29. Silvia, N.L.; Maria, V.C. In vitro antifungal properties, structure-activity relationships and studies on the mode of action of $\mathrm{N}$-phenyl, $\mathrm{N}$-aryl, $\mathrm{N}$-phenylalkyl maleimides and related compounds. Arzneim-Forsch 2005, 55, 123-132.

30. Slavica, A.; Dib, I.; Nidetzky, B. Selective modification of surface-exposed thiol groups in Trigonopsis variabilis D-amino acid oxidase using poly (ethylene glycol) maleimide and its effect on activity and stability of the enzyme. Biotechnol. Bioeng. 2007, 96, 9-17. [CrossRef] [PubMed]

31. Manas, K.S.; Debjani, D.; Dulal, P. Pyrene excimer fluorescence of yeast alcohol dehydrogenase: A sensitive probe to investigate ligand binding and unfolding pathway of the enzyme. Photochem. Photobiol. 2006, 82, 480-486.

32. Wu, P.; Hu, Y.Z. Synthesis of novel 1,4-benzoxazine-2,3-dicarboximides from maleic anhydride and substituted aromatic amines. Synth. Commun. 2009, 39, 70-84. [CrossRef]

33. Sortino, M.; Garibotto, F.; Cecheinel, F.V.; Gupta, M.; Enriz, R.; Zacchino, S. Antifungal, cytotoxic and SAR studies of a series of $N$-alkyl, $N$-aryl and $N$-alkylphenyl-1,4-pyrrolediones and related compounds. Bioorg. Med. Chem. 2011, 19, 2823-2834. [CrossRef] [PubMed]

34. Natalia, S.; Joanna, B.M. Chemical reactivity and antimicrobial activity of $N$-substituted maleimides. J. Enzyme Inhib. Med. Chem. 2011, 27, 117-124.

35. Jerzy, K. Synthesis of new $N$-substituted cyclic imides with potential anxiolytic activity. XXV. derivatives of halogenodibenzo(e.h)bicyclo(2.2.2)otcane-2,3-dicarboximide. Acta Pol. Pharm. 2003, 60, 1183-1189.

36. Nara, L.M.; Gislaine, F.; Carla, S. N-antipyrine-3,4-dichloromaleimide, an effective cyclic imide for the treatment of chronic pain: the role of the glutamatergic system. Anesth. Analg. 2010, 110, 942-950.

37. Khan, M.I.; Baloch, M.K.; Ashfaq, M. Biological aspects of new organotin (IV) compounds of 3-maleimidopropionic acid. J. Organomet. Chem. 2004, 689, 3370-3378. [CrossRef]

38. Sosabowski, J.K.; Matzow, T.; Foster, J.M.; Finucane, C.; Ellison, D.; Watson, S.A.; Mather, S.J. Targeting of CCK-2 receptor-expressing tumors using a radiolabelled divalent gastrin peptide. J. Nucl. Med. 2009, 50, 2082-2089. [CrossRef] [PubMed]

39. Yu, X.Y.; Corten, C.; Gornerc, H.; Wolff, T.; Kuckling, D. Photodimers of N-alkyl-3, 4-dimethylmaleimidesproduct ratios and reaction mechanism. J. Photochem. Photobiol. 2008, 198, 34-44. [CrossRef]

40. Jiang, L.; Liu, F.; Zhang, D.K.; Wang, H.B. Synthesis and antifungal activity of 1-substitutedphenyl-3(5-halobenzimidazol-2-yl) acylurea. J. Pestic. Sci. 2010, 35, 33-35. [CrossRef]

41. Takatori, K.; Hasegawa, T.; Nakano, S. Antifungal activities of $N$-substituted maleimide derivatives. Microbiol. Immunol. 1985, 29, 1237-1241. [CrossRef] [PubMed]

42. Trujillo-Ferrara, J.; Santillan, R.; Beltran, H.I. ${ }^{1} \mathrm{H}$ and ${ }^{13} \mathrm{C}-\mathrm{NMR}$ spectra for a series of arylmaleamic acids, arylmaleimides, arylsuccinamic acids and arylsuccinimides. Magn. Reson. Chem. 1999, 37, 682-686. [CrossRef]

43. Sortino, M.; Zacchino, S.A. Efficient asymmetric hydrogenation of the C-C double bond of 2-methyl-N-phebylalkylmaleimides by Aspergillus fumigatus. Tetrahedron Asym. 2010, 21, 535-539. [CrossRef]

44. Rahman, A.A.; Samoylenko, V.; Jacob, M.R.; Sahu, R.; Jain, S.K.; Khan, S.I.; Tekwani, B.L.; Muhammad, I. Antiparasitic and antimicrobial indolizidines from the leaves of Prosopis glandulosa var. glandulosa. Planta Medica 2011, 77, 1639-1643. [CrossRef] [PubMed]

45. Mikus, J.; Steverding, D. A simple colorimetric method to screen drug cytotoxicity against Leishmania, using the dye Alamar Blue. Parasitol. Int. 2000, 48, 265-269. [CrossRef]

Sample Availability: Samples of the compounds are not available from the authors. 